\title{
Effects of Water Saving Practices on Winter Wheat and Summer Maize Yields in South Loess Plateau of Northwest China
}

\author{
Ahmadzai MA ${ }^{1}$, Cai $\mathbf{M}^{1}$, Meng $\mathbf{Y}^{1}$ and $Z$ hou JB ${ }^{1,2^{*}}$ \\ ${ }^{1}$ College of Natural Resources and Environment, Northwest A\&F University, Yangling, Shaanxi 712100, China \\ ${ }^{2}$ Key Laboratory of Plant Nutrition and the Agri-environment in Northwest China, Ministry of Agriculture, Yangling, Shaanxi 712100, China
}

"Corresponding author: Zhou JB, College of Natural Resources and Environment, Northwest A\&F University, Yangling, Shaanxi 712100, China, Tel: +862987082793; E-mail: jbzhou@nwsuaf.edu.cn

Received date: June 07, 2017; Accepted date: July 04, 2017; Published date: July 11, 2017

Copyright: (c) 2017 Ahmadzai MA, et al. This is an open-access article distributed under the terms of the Creative Commons Attribution License, which permits unrestricted use, distribution, and reproduction in any medium, provided the original author and source are credited.

\begin{abstract}
A field experiment, laid out in Randomized Complete Block Design (RCBD) with split plot arrangement having four replications, was conducted at the south edge of Loess Plateau, Shaanxi, China to evaluate the responses of winter wheat and summer maize to different water saving management practices involving four mulching and irrigation treatments, i.e., plastic mulch ridge and straw mulch furrow combined with deficit irrigation (RF+DI), straw mulch combined with deficit irrigation (SM+DI), Deficit Irrigation (DI), and Conventional Flood Irrigation (CFI). Soil temperature and moisture during the crop growth were monitored in two years. RF+DI treatment significantly increased maize yield, and it also had higher wheat yield than SM+DI treatment. SM+DI treatment increased maize yield; however, it did not increase winter wheat yield. Soil water content in RF+DI and SM+DI treatments was significantly higher than those of CFI or DI treatments. Compared with RF+DI treatment, SM+DI treatment had higher soil water content $(0-20 \mathrm{~cm})$; however, it had the lowest heat 741 Degree Days of Soil (DDs) among the four treatments. The low soil temperature in SM+DI plots, especially in early spring, delayed winter wheat growth stages and development, thus reduced grain yield compared with $R F+D I$ treatment. The positive effects of ridge-furrow system on both wheat and maize yield could be explained by harmonizing soil moisture and temperature by this treatment.
\end{abstract}

Keywords: Water saving practices; Winter wheat; Summer maize; Soil temperature; Soil moisture

\section{Introduction}

The rapidly growing human population of 7.14 billion is expected to rise up to 8.1 billion by 2030 . This population increase will in turn lead to a considerable additional demand for food [1]. At the same time, water use has been growing at more than twice the rate of population increase in the last century. So, a great challenge for agriculture is to produce more food from limited water which can be achieved by increasing crop water productivity [2]. Water shortage is one of the most important factors limiting crop yield worldwide, especially in dry land farming [3-5]. Therefore, different water saving practices are used to conserve water in dry land farming [6,7]. Results of the long-term research suggests that mulching significantly reduced bulk density and penetration resistance; increased organic carbon, saturated hydraulic conductivity, water stable aggregate microbial biomass carbon and soil enzyme activities. Additionally, together mulching and irrigation regulates soil as well as canopy temperature that helps in developing better root system which in turn results into better nutrient uptake and plant withstanding against high velocity winds at grain filling/maturity (reduce lodging) [8-11]. Straw mulch is one of the efficient ways to alter water distribution between soil evaporation and plant transpiration, and is applied to a number of crops, including wheat [12], maize [13-15], groundnut [16], and onion [17]. The responses of different crops to straw mulch practices, however, have been variable. Wheat grain yields were positively influenced by straw mulch treatments $[18,19]$. Tomato yields from straw mulched plot were higher than those from non-mulched treatments [20]. Yield responds of maize to straw mulch practices, however, remained contentious. While many researchers observed highly significant yield difference from straw compared with conventional methods [21-23]. Straw mulch significantly decreased wheat yield. The different responses of crops to straw mulch are related to their types and climatic conditions [24,25]. The ridge and furrow technique is another widely used water saving practice. In this technique, the plastic-covered ridges serve as rainfallharvesting zones and the straw mulched furrows serve as planting zones [26]. Many researchers have studied the effects of ridges-furrow cultivation combined with plastic or straw mulch on wheat and maize crop yield and revealed that the ridge-furrow treatment produced high wheat and maize yields compared to the conventional cultivation treatment [27-30]. Ridge-furrow technique has been successfully applied to a number of crops including onion [31], sweet sorghum [32], alfalfa [33], potatoes and proso millet [34,35]. After all, ridgefurrow practices coupled with mulch seems to be one of the most effective ways to improve water use efficiency and increase crop yields. Winter wheat (Triticum aestivum L.) and summer maize (Zea mays L.) rotation is an intensive production system in north China, including the North China Plain (NCP), and Guanzhong Plain. It plays an important role in cereal production in China. For example, The NCP accounts for about $69 \%$ of wheat and $35 \%$ of maize grain yields of the whole country $[36,37]$. The water requirements of double cropping system of winter wheat and summer maize exceed $850 \mathrm{~mm}$. Long-term average annual precipitations in the NCP ranges from 450 to $650 \mathrm{~mm}$ with $70 \%$ falling from July to September, the growing season of maize. During the growing season of winter wheat, rainfall could only meet $25-40 \%$ of the crop water requirements [15]. Therefore, irrigation is needed for this rotation. The groundwater is the main water resource in this region. The excessive exploitation of groundwater resources 
from shallow and deep aquifers has caused falling water tables and many other environmental problems (e.g. land subsidence) within the plain [36]. To increase the water use efficiency is thus an ultimate need to be fulfilled in the region. Using the different water saving methods of the dry land farming could be one solution. However, most of the studies have focused on deficit irrigation, and straw mulch $[19,28]$. Deficit Irrigation (DI) is an optimization strategy which is being used for the reduction of water use and for the increasing of Water Use Efficiency (WUE) in many parts of the world [19]. Few studies compare the effects of the different water saving methods both on soil moisture and temperature in winter wheat and summer maize rotation. The objective of this study was to compare the effects of different water saving practices on yield responses of winter wheatsummer maize crops at the south edge of loess plateau, and relate their responses with soil moisture and temperature.

\section{Materials and Methods}

\section{Site description}

Field experiment was conducted at the No. 1 Experimental Station of the Northwest A\&F University, Yangling, Shaanxi, China ( $34^{\circ} 17$ $\left.56^{\prime \prime} \mathrm{N}, 108^{\circ} 04^{\prime} 07^{\prime \prime} \mathrm{E}\right)$. The climate is temperate and sub-humid with mean annual precipitation of $632 \mathrm{~mm}$ and mean annual air temperature of $13^{\circ} \mathrm{C}$. Winters are long (early December-march) with scanty precipitation. Almost $60 \%$ of the precipitation occurs from July to September. Mean annual pan evaporation of the area is $1400 \mathrm{~mm}$. The soil of the experimental field is characterized by Eum-Orthic Anthrosols. The selected properties of soil are given in Table 1.

\begin{tabular}{|l|l|l|l|l|l|l|}
\hline $\mathbf{p H}$ & $\begin{array}{l}\text { Organic } \\
\mathbf{m a t t e r} \\
\mathbf{( g / k g )}\end{array}$ & $\begin{array}{l}\text { Total } \mathbf{N} \\
(\mathbf{g} / \mathbf{k g})\end{array}$ & $\begin{array}{l}\mathbf{N O}_{3}-\mathbf{N} \\
(\mathbf{k g} / \mathbf{h a})\end{array}$ & $\begin{array}{l}\mathbf{N H}_{4}-\mathbf{N} \\
(\mathbf{m g} / \mathbf{k g})\end{array}$ & $\begin{array}{l}\text { Olsen-P } \\
(\mathbf{m g} / \mathbf{k g})\end{array}$ & $\begin{array}{l}\mathbf{N H}_{4} \mathrm{OAc}-\mathrm{K} \\
(\mathbf{m g} / \mathbf{k g})\end{array}$ \\
\hline 8.25 & 15.2 & 0.67 & 30.4 & 1.9 & 17.2 & 169 \\
\hline
\end{tabular}

Table 1: Selected chemical properties of the soil prior to planting in 2003.

\section{Experimental design and field layout description}

The study began in June, 2009. The experiment was laid out in a split plot design with four main plot treatments, namely (1) conventional flood irrigation (CFI), (2) deficit irrigation (DI), (3) straw mulch+deficit irrigation $(\mathrm{SM}+\mathrm{DI})$, and (4) plastic mulch ridge straw mulch furrow+deficit irrigation $(\mathrm{RF}+\mathrm{DI})$. The last three treatments were considered as water saving management practices. Three nitrogen fertilizer rates, i.e., 0,120 , and $240 \mathrm{~kg} \mathrm{ha}^{-1}$ were the sub plot treatments. The main plot size was $4.5 \times 12 \mathrm{~m}$, replicated four times. Briefly, there was no straw or plastic film mulch applied in CFI and DI treatments. $\mathrm{RF}+\mathrm{DI}$ treatment was consisted of intermittent ridges and furrows. The ridges were $30 \mathrm{~cm}$ wide and $15 \mathrm{~cm}$ high while the furrows were $30 \mathrm{~cm}$ wide. Ridges were mulched with plastic, and furrows were mulched with straw. Wheat cultivar (Xiaoyan-22) was sown as row crop system in early October and harvested in early June. Row to row space in the CFI, WS and SM+DI treatments was $20 \mathrm{~cm}$, and each plot had 21 rows. In the $\mathrm{RF}+\mathrm{DI}$ treatment, no wheat was sown on the ridges, each furrow had two rows. There were 16 rows in the RF+DI treatment. The plots were sprayed with weedicides. Maize cultivar (Zhengdan-958) was planted immediately after wheat harvest without tilling the soil. The holes were drilled by adze with rows $60 \mathrm{~cm}$ apart and $5 \mathrm{~cm}$ deep. Maize was seeded in each hole, and then the holes were filled with soil. In the
$\mathrm{RF}+\mathrm{DI}$ treatment, the ridges were mulched instantly with plastic. A more detailed description of the experiment is given by Zhou et al. [19].

\section{Soil sampling and measurements}

During the crop growing season in 2011, 2012 and 2013; the Geothermometers (Tidbit v2 Temp logger, USA) were placed $10 \mathrm{~cm}$ deep in soil. Soil temperature was calculated at one hour intervals during day and night. The daily mean soil temperature $\left({ }^{\circ} \mathrm{C}\right)$ was considered as the average of all intra-day reading. Soil heat accumulation was measured as degree days of soil (DD soil) (Juan C. Diaz-Perez, 2009). It was calculated as:

$$
\text { DDsoil }=\sum_{i=1}^{i=n} \frac{1}{2}\left\{\frac{\text { RZTmax }+ \text { RZTmin }}{2}-\text { RZTbase }\right\}
$$

Where $n$ is the number of days in the growing season, RZTmax and $R Z T m i n$ are the daily maximum and minimum soil temperatures and $R Z T$ Tase is the base root zone temperature. Soil moisture was gravimetrically measured at $20 \mathrm{~cm}$ increments down to $200 \mathrm{~cm}$ after harvesting the crop, manually using a soil auger. A core of soil sample was collected from each plot. Soil water content in the top $20 \mathrm{~cm}$ of soil was measured with TDR in each plot at 25-30 days intervals during crop growing season. The Volumetric water contents were calculated by multiplying the gravimetric soil moisture with bulk density value for soil.Soil moisture was gravimetrically measured at $20 \mathrm{~cm}$ increments down to $200 \mathrm{~cm}$ after harvesting the crop, manually using a soil auger. A core of soil sample was collected from each plot. Soil water content in the top $20 \mathrm{~cm}$ of soil was measured with TDR in each plot at 25-30 days intervals during crop growing season. The Volumetric water contents were calculated by multiplying the gravimetric soil moisture with bulk density value for soil.

\section{Statistical analysis}

The data were assessed by Analysis of Variance (ANOVA) employing statistical software Statistix 8.1 and the Least Significant Difference (LSD) test at $\mathrm{P}<0.05$ was opted for multiple comparisons.

\section{Results}

\section{Crop grain yield}

Compared to other water saving treatments, the RF+DI treatment produced slightly more wheat grain yield. However, the difference was not statistically significant (Table 2).

\begin{tabular}{|l|l|l|l|l|l|l|}
\hline Treatments & 2010 & $\mathbf{2 0 1 1}$ & $\mathbf{2 0 1 2}$ & $\mathbf{2 0 1 3}$ & Average & Total \\
\hline RF+DI & $3250 \mathrm{~A}$ & $4320 \mathrm{~A}$ & $2670 \mathrm{~A}$ & $1710 \mathrm{~A}$ & $2990 \mathrm{~A}$ & $11950 \mathrm{~A}$ \\
\hline DI & $2990 \mathrm{~A}$ & $3790 \mathrm{~A}$ & $2740 \mathrm{~A}$ & $1340 \mathrm{~A}$ & $2715 \mathrm{~A}$ & $10860 \mathrm{~A}$ \\
\hline SM+DI & $2990 \mathrm{~A}$ & $3560 \mathrm{~A}$ & $2830 \mathrm{~A}$ & $1360 \mathrm{~A}$ & $2685 \mathrm{~A}$ & $10740 \mathrm{~A}$ \\
\hline CFI & $3020 \mathrm{~A}$ & $3950 \mathrm{~A}$ & $2910 \mathrm{~A}$ & $1120 \mathrm{~A}$ & $2750 \mathrm{~A}$ & $11000 \mathrm{~A}$ \\
\hline All & & & &
\end{tabular}

All means followed by different letters relating to same parameter are statistically different at $(\mathrm{P}<0.05)$ level using the LSD. RF: Ridge-Furrow; DI: Deficit Irrigation; SM: Straw Mulch; CFI: Conventional Flood Irrigation

Table 2: Effect of water saving management practices on winter wheat grain yield $\left(\mathrm{kg} \mathrm{ha}^{-1}\right)$. 
Different water management practices significantly affected the maize yield compared to the conventional treatment. Over the five years study, total maize yield in the RF+DI treatment was $8970 \mathrm{~kg} \mathrm{ha}^{-1}$ (25.23\%) more than in the DI treatment and $9450 \mathrm{~kg} \mathrm{ha}^{-1}(26.58 \%)$ more than in the CFI treatment.

Compared to the CFI and DI treatments, SM+DI treatment produced $19.04 \%$ and $17.55 \%$ more maize yield respectively (Table 3 ). This indicates that the use of straw or plastic as mulch has a significant influence on maize grain yield.

\begin{tabular}{|l|l|l|l|l|l|l|l|}
\hline Treatments & 2009 & $\mathbf{2 0 1 0}$ & $\mathbf{2 0 1 1}$ & $\mathbf{2 0 1 2}$ & $\mathbf{2 0 1 3}$ & Average & Total \\
\hline RF+DI & $5570 \mathrm{~A}$ & $7740 \mathrm{~A}$ & $6700 \mathrm{~A}$ & $7860 \mathrm{~A}$ & $7680 \mathrm{~A}$ & $7110 \mathrm{~A}$ & $35550 \mathrm{~A}$ \\
\hline DI & $3820 \mathrm{~B}$ & $6060 \mathrm{~B}$ & $5450 \mathrm{C}$ & $5830 \mathrm{C}$ & $5420 \mathrm{C}$ & $5316 \mathrm{C}$ & $26580 \mathrm{C}$ \\
\hline SM+DI & $5050 \mathrm{~A}$ & $7300 \mathrm{~A}$ & $6060 \mathrm{~B}$ & $7010 \mathrm{~B}$ & $6820 \mathrm{~B}$ & $6448 \mathrm{~B}$ & $32240 \mathrm{~B}$ \\
\hline CFI & $4100 \mathrm{~B}$ & $5720 \mathrm{~B}$ & $5100 \mathrm{C}$ & $6400 \mathrm{BC}$ & $4780 \mathrm{D}$ & $5220 \mathrm{C}$ & $26100 \mathrm{C}$ \\
\hline
\end{tabular}

Note: numbers within a column followed by different letters are significantly different at 0.05 levels (LSD). RF: Ridge-Furrow; DI: Deficit Irrigation; SM: Straw Mulch; CFI: Conventional Flood Irrigation.

Table 3: Effect of water saving management practices on summer maize grain yields $\left(\mathrm{kg} \mathrm{ha}^{-1}\right)$.

\section{Soil moisture}

The objective of this study was to compare the effects of different water saving practices on yield responses of winter wheat-summer maize crops at the south edge of loess plateau, and relate their responses with soil moisture and temperature.

Either straw or plastic film mulch had significant effect on soil moisture (Table 4). Compared with DI treatment, the average soil water storage $(0-20 \mathrm{~cm})$ over 2012-2013 winter wheat season at different growth stages was significantly increased with RF+DI, SM +DI, and CFI by $11.5 \%, 19.6 \%$ and $13.6 \%$ respectively (Table 4 ).

At post-harvest time of maize in 2012, water saving management practices significantly affected soil water storage at top soil but there was no remarkably difference in low profile water storages (Figure 1A), although the differences were not significant among treatments at post-harvest time of winter wheat in 2013 (Figure 1B).

Compared to CFI treatment, $\mathrm{SM}+\mathrm{DI}$ and $\mathrm{RF}+\mathrm{DI}$ treatment had more water at upper soil profile.

\begin{tabular}{|l|l|l|l|l|}
\hline Treatments & March 2013 & April 2013 & May 2013 & Sum \\
\hline RF+DI & $19.5 \mathrm{~B}$ & $42.5 \mathrm{~A}$ & $15.7 \mathrm{~B}$ & $77.7 \mathrm{AB}$ \\
\hline DI & $18.5 \mathrm{~B}$ & $34.7 \mathrm{~B}$ & $15.5 \mathrm{~B}$ & $68.7 \mathrm{~B}$ \\
\hline SM+DI & $23.4 \mathrm{~A}$ & $42.1 \mathrm{~A}$ & $19.8 \mathrm{~A}$ & $85.3 \mathrm{~A}$ \\
\hline CFI & $18.8 \mathrm{~B}$ & $40.5 \mathrm{AB}$ & $20.3 \mathrm{~A}$ & $79.6 \mathrm{AB}$ \\
\hline
\end{tabular}

All means followed by different letters relating to same parameter are statistically different at $(P<0.05)$ level using the LSD. RF: Ridge-Furrow; DI: Deficit Irrigation; SM: Straw Mulch; CFI: Conventional Flood Irrigation

Table 4: Soil water content $(\mathrm{mm})$ at $0-20 \mathrm{~cm}$ depth for the different cultural practices at March (Tillering), April (Booting) and May (Late Flowering) stages during winter wheat season in 2013.

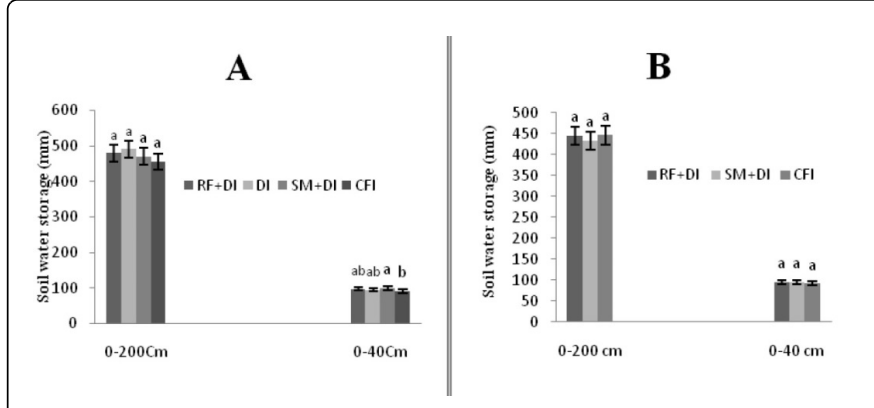

Figure 1: Soil profile $(0-200 \mathrm{~cm})$ water storage $(\mathrm{mm})$ for different cultural practices at post-harvest time of 2012 summer maize crop (Figure 1A) and at post-harvest time of 2012-2013 winter wheat (Figure 1B). CFI: Conventional Flood Irrigation; SM: Straw Mulch; DI: Deficit Irrigation; RF: Ridge-Furrow.

\section{Soil temperature}

The interim variations in soil temperature with all the treatments during 2011-2012 and 2012-2013 wheat growing were affected by mulch practices (Figure 2). Diurnal changes in soil temperature, measured daily at $10 \mathrm{~cm}$ depth, showed that daily mean soil temperature was higher in straw mulch+DI than in CFI plots during the cold winter (Figure 2a). At that time, the soil temperature fell to $0.79^{\circ} \mathrm{C}$ in the $\mathrm{CFI}$ and to $1.3^{\circ} \mathrm{C}$ in $\mathrm{SM}+\mathrm{DI}$ plots and then rose steadily, peaked at $22.5^{\circ} \mathrm{C}$ in $\mathrm{CFI}$ and $21.3^{\circ} \mathrm{C}$ in the $\mathrm{SM}+\mathrm{DI}$ treatments. During wheat growing season in 2013 (Figure 2b), soil temperature fell from late October to early February and then rose rapidly, peaked at $24.08^{\circ} \mathrm{C}$ in CFI and $22.7^{\circ} \mathrm{C}$ in the SM+DI treatments at late May 2013. Mean diurnal soil temperature under straw mulch treatment was $0.7^{\circ} \mathrm{C}$ warmer than in the CFI treatment in cold winter (Figure 2b).

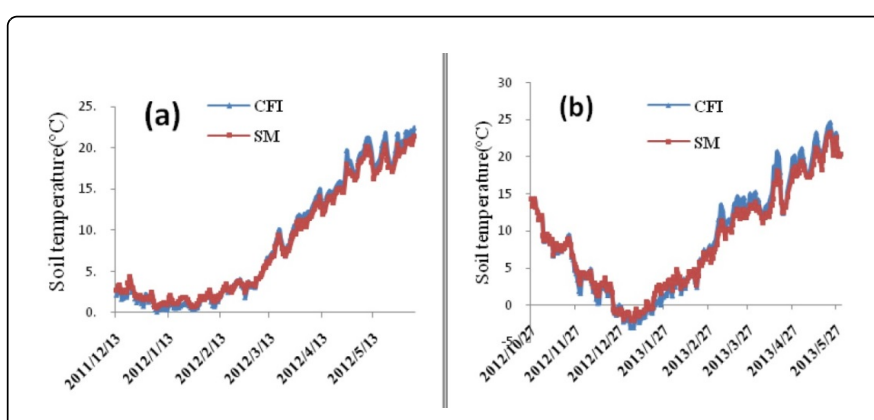

Figure 2: Changes of diurnal temperature of soil at $10 \mathrm{~cm}$ depth during the 2011-2012 (a) and 2012-2013 (b) winter wheat growing season in CFI and SM+DI plots. CFI: Conventional Flood Irrigation; SM: Straw Mulch; DI: Deficit Irrigation.

The soil temperature in $\mathrm{RF}+\mathrm{DI}$ treatment was recorded in both plastic mulched ridge and straw mulched furrow. For the 2011-2012 wheat growing season, there was no significant difference between straw mulch furrow and plastic mulch ridge in soil temperature during winter; with the beginning of spring, plastic mulch ridge kept soil warmer than straw mulch furrow (Figure 3a). During wheat growing season in 2012-2013, the difference in soil temperature at $10 \mathrm{~cm}$ depth between plastic mulch ridge and straw mulch furrow evidenced that soil temperature had the same status during colder weather, but 
thereafter was a significant difference among straw mulch furrow and plastic mulch ridge in thermal regime. For 2012-2013 winter wheat growing season, the soil temperature regime was similar to that in 2011-2012, but the only difference in soil temperature of these two winter wheat growing seasons was that soil temperature in 2012-2013 winter seasons fell down to below zero in late December and early January (Figure 3b). For wheat growing period, the mean soil temperature beneath the plastic mulched ridge was higher than those of straw mulched (SM+DI) or Conventional Flood Irrigation (CFI).

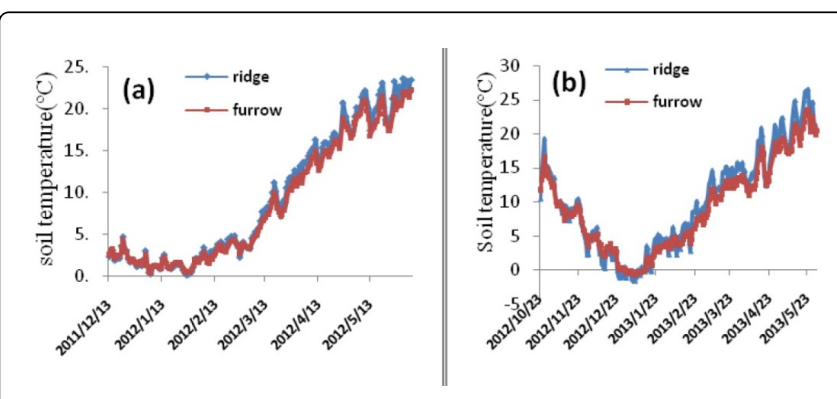

Figure 3: Changes of diurnal temperature of soil at $10 \mathrm{~cm}$ depth during the 2012-2013 and 2012-2013 winter wheat growing seasons in the ridge and furrow of RF+DI treatment.

The effect of SM+DI or RF+DI on soil temperature was larger during the early stages of maize growth, and their effects decreased with maize growth (Figure 4). The soil temperature at 0-10 cm depth was consistently higher in the plastic mulch ridge than the straw mulch furrow (Figure $4 \mathrm{~b}$ ). There was no significant difference in mean soil temperature during whole growing season among the treatments. However, straw mulch kept the soil cooler in hot summer compared to CFI (Figure 4a).
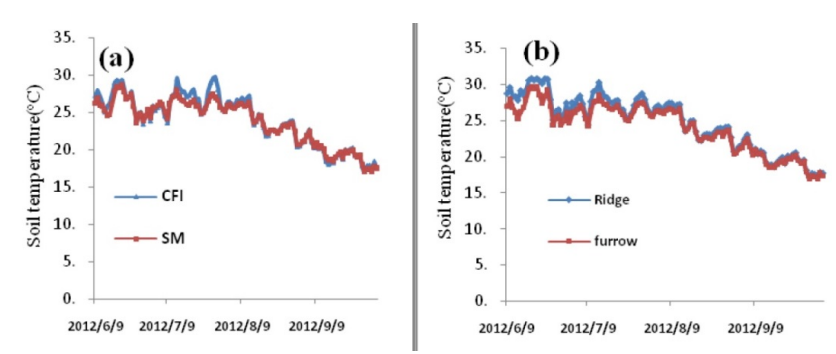

Figure 4: Diurnal trends in soil temperature $\left({ }^{\circ} \mathrm{C}\right)$ at $10 \mathrm{~cm}$ depth under straw mulch and conventional treatments (Pannel-A), plastic mulch ridge and straw mulch furrow in RF+DI treatment (PannelB) during 2012 maize growing season. CFI: Conventional Flood Irrigation; SM: Straw Mulch.

\section{Soil heat accumulation}

The amount of heat accumulated in the soil, measured as soil degree-days (DD soil) or heat units, differed among seasons $(\mathrm{P}<0.05)$ and water saving management practices. The mean, maximum and minimum root zone temperatures for all water saving management practices during the three seasons are shown in Table 5. Less heat was accumulated in the soil during the 2011-2012 winter wheat growing season in $\mathrm{SM}+\mathrm{DI}$ treatment compared to the CFI treatment. While plastic mulch ridge in $\mathrm{RF}+\mathrm{DI}$ treatment accumulated the highest $\mathrm{DD}$ soil. In particular, from the begin of spring to harvest of 2011-2012 winter wheat, accumulated soil temperature under SM+DI was 611 DD soil while CFI had 647 DD soil accumulated heat. The same difference in accumulated soil temperature was found for 2012-2013 wheat season whereas SM+DI had 716 DD soil and CFI had 658 DD soil accumulated heat.

During 2012 summer maize growing season, in the RF+DI treatment, plastic mulch ridge accumulated much DD soil compared to the SM+DI, but there was no significant difference among straw mulch furrow in the RF+DI, CFI and $\mathrm{SM}+\mathrm{DI}$ in soil heat accumulation. In general, the plastic much ridge accumulated more DD soil than other treatments, and there was least accumulation of heat units (DD soil) in SM+DI treatment.

\begin{tabular}{|l|l|l|l|l|}
\hline Treatment & Mean ('C) & Maximal ('C) & Minimal ('C) & $\begin{array}{l}\text { Accumulated } \\
\text { heat (DDs) }\end{array}$ \\
\hline \multicolumn{5}{|c|}{ 2011-2012 winter wheat season } \\
\hline PR in RF+DI & 9.32 & 11.9 & 7.51 & 849 A \\
\hline SF in RF+DI & 8.77 & 10.27 & 7.56 & 780 B \\
\hline SM+DI & 8.32 & 9.73 & 7.2 & 741 C \\
\hline CFI & 8.59 & 10.58 & 7.11 & 774 C \\
\hline \multicolumn{5}{|c|}{2012 maize season } \\
\hline PR in RF+DI & 24.73 & 27.28 & 22.65 & 883 A \\
\hline SF in RF+DI & 24 & 25.77 & 22.45 & 833 B \\
\hline SM+DI & 23.68 & 25.59 & 22.09 & 816 B \\
\hline CFI & 24.05 & 26.79 & 21.81 & 844 B \\
\hline \multicolumn{5}{|c|}{$2012-2013$ winter wheat season } \\
\hline PR in RF+DI & 9.96 & 16.1 & 6.12 & 1200 A \\
\hline SF in RF+DI & 9.16 & 11.3 & 7.51 & 1015 C \\
\hline SM+DI & 8.66 & 11.56 & 6.52 & 967 C \\
\hline CFI & 8.9 & 12.67 & 6.18 & 1018 C \\
\hline $\begin{array}{l}\text { Note: Numbers within a column followed by different letters are significantly } \\
\text { Mulch; DI: Deficit Irrigation; PR: Plastic Mulch Ridge; SF: Straw Mulch Furrow }\end{array}$ \\
\hline
\end{tabular}

Table 5: the seasonal average Root Zone Temperatures (RZT) during the 2011-2012, 2012-2013 winter wheat and 2012 summer maize growing seasons as affected by different cultural practices.

\section{Discussion}

\section{Effects of straw mulch on crop yields}

Numerous reports indicate that straw mulching increases soil moisture [38-40]. However, its effects on crop yields are variable. Straw mulch can significantly affect the soil microclimate (soil temperature and water content) and hence grain yield of maize [13,17-19], wheat [15,21], radish [15], and tomatoes [16]. Current results revealed that, compared to the CFI treatment, straw mulch slightly decreased wheat yield, but significantly increased summer maize grain yield. Reason for the different responses of winter wheat and summer maize to straw 
mulch is related to its effect on soil moisture and temperature during the crop growth. It was depicted that soil moisture of straw mulch treatment in early spring was higher than that of the CFI treatment (Table 4); however, the soil temperature of in straw mulch treatment was lower than that in the CFI treatment (Figure 2). Compared to the moisture, soil temperature is more important for winter wheat growth in this period. Low temperature in early spring delayed wheat growth. The responses of wheat yield to straw mulch in current study are in agreement with the results of Chen et al. [20] who also observed that straw mulch had negative effect on winter wheat yield.

Compared to soil temperature, water availability is a key factor to summer maize growth during the hot summer. The straw mulch reduces soil evaporation, and conserves more moisture in soil [5,7]. Results show that it also decreased soil temperature compared to CFI treatment (Figure 4 and Table 5). These results for straw mulch effects on soil temperature are in line with the work of Zhang et al. [15], who found that soil temperatures under straw mulch at $10 \mathrm{~cm}$ depth were decreased in warmer period by $0-4^{\circ} \mathrm{C}$ and increased in the colder period by $0-2^{\circ} \mathrm{C}$ compared to non-mulched soil. Cooler soil's temperature and higher water content under straw much treatment could be the positive maize grain response in SM+DI compared to CFI treatment. Obviously the responses of different crops to straw mulch are dependent on crop types, and climate conditions.

\section{Effects of ridge-furrow technique on crop yields}

Previous studies have shown that plastic mulch and ridge-furrow technique greatly increased yield of cereals, which is mainly due to the effect of plastic film on reducing water evaporation from soil $[6,7,21]$. Our study also found that this technique not only slightly increased winter wheat yield, but also significantly improved summer maize grain yields compared to the other three treatments (Tables 2 and 3). Similar findings reported by other researchers stated that the integrated effect of ridge-furrow system and supplemental irrigation increased maize yield by $106 \%[7,21,38]$. It is also reported that the ridge and furrow technique could be an optimal practice to improve runoff efficiency, rain water harvesting and crop yield [39]. This cultivation system was applied on onion [28], maize [5,7,40], wheat $[21,38]$, sorghum [23], and alfalfa [22]. The positive effect of ridgefurrow system could be explained by the coupling of favorable changes in moisture and temperature by this treatment. Plastic mulching on the ridge led to more heat adsorption during winter, and straw mulched furrow helped soil to conserve more water for crop.

The different responses of winter wheat and summer maize yields to $\mathrm{RF}+\mathrm{DI}$ system in current study is also due to the reason that RF practices reduced the area planted to wheat (from 21 rows of wheat in the CFI to 14 rows in RF+DI plots), while the planted to maize did not change [5]. Ridge-furrow rainfall harvesting system with mulches is being promoted to increase water availability for crops in areas of the Loess Plateau of China [29,39]. However, the efficiency of this system is dependent on the width ratios of ridges and furrows, cultivating crop, land topography, and regional climate. Further research is needed to find the optimum width ratios of ridges and furrows for different crops at the different regions.

\section{Conclusion}

Compared to the DI or CFI treatments, both $\mathrm{SM}+\mathrm{DI}$ and $\mathrm{RF}+\mathrm{DI}$ treatments had positive effects on water content in soil profiles. RF+DI treatment significantly increased maize yield, and it also had higher wheat yield than $S M+D I$ treatment. SM+DI treatment increased maize yield; however, it did not increase winter wheat yield. The reason is that straw mulch decreased soil temperature during the early spring, that delayed winter wheat growth stages and development thus reduced final grain yield. Compared to the SM+DI treatment, the RF+DI treatment harmonizes the soil moisture and temperature. Therefore, it increases both wheat and maize yields.

\section{Acknowledgements}

The authors would like to acknowledge the financial support of the National Natural Science Foundation of China (31372137), and the 111 Project (No. B12007).

\section{References}

1. Ali MH, Talukder MSU (2008) Increasing water productivity in crop production-a synthesis. Agric Water Manag 95: 1201-1213.

2. Zwart SJ, Bastiaanssen WG (2004) Review of measured crop water productivity values for irrigated wheat, rice, cotton and maize. Agric Water Manag 69: 115-133.

3. Doring TF, Brandt M, Heb J, Finckh MR, Saucke H (2005) Effects of straw mulch on soil nitrate dynamics, weeds, yield and soil erosion in organically grown potatoes. Field Crop Res 94: 238-249.

4. Fischer G, Tubiello FN, Van Velthuizen H Wiberg DA (2007) Climate change impacts on irrigation water requirements: effects of mitigation, 1990-2080. Technol Forecast Soc 74: 1083-1107.

5. Zhao H, Xiong YC, Li FM, Wang RY, Qiang SC, et al. (2012) Plastic film mulch for half growing-season maximized WUE and yield of potato via moisture-temperature improvement in a semi-arid agroecosystem. Agric Water Manag 104: 68-78.

6. Ye JS, Liu CA (2012) Suitability of mulch and ridge-furrow techniques for maize across the precipitation Gradient on the Chinese Loess Plateau. J Agric Sci 4: 182-190.

7. Liu Y, Li S, Chen F, Yang S, Chen X (2010) Soil water dynamics and water use efficiency in spring maize (Zea mays L.) fields subjected to different water management practices on the Loess Plateau, China. Agric Water Manag 97: 769-775.

8. Parihar CM, Jat SL, Singh AK, Majumdar K, Jat ML, et al. (2017) Bioenergy, water-use efficiency and economics of maize-wheat-mungbean system under precision-conservation agriculture in semi-arid agroecosystem. Energy 119: 245-256.

9. Gathala MK, Jat ML, Saharawat YS, Sharma SK Ladha JK (2017) Physical and chemical properties of a sandy loam soil under irrigated rice-wheat sequence in the Indo-Gangetic Plains of South Asia. J Ecosyst Ecogra.

10. Weindorf DC, Sarkar R, Dia M, Wang H, Chang Q, et al. (2008) Correlation of X-ray fluorescence spectrometry and inductively coupled plasma atomic emission spectroscopy for elemental determination in composted products. Compost Sci Util 16: 79-82.

11. Weindorf D, Rinard B, Zhu Y, Johnson S, Haggard B, et al. (2008) High resolution soil survey of capulin volcano national monument, New Mexico. Soil Horizons 49: 55-62.

12. Chakraborty D, Nagarajan S, Aggarwal P, Gupta VK, Tomar RK, et al. (2008) Effect of mulching on soil and plant water status, and the growth and yield of wheat (Triticum aestivum L.) in a semi-arid environment. Agric Water Manag 95: 1323-1334.

13. Wang TC, Wei L, Wang HZ, Ma SC, Ma BL (2011) Responses of rainwater conservation, precipitation-use efficiency and grain yield of summer maize to a furrow-planting and straw-mulching system in northern China. Field Crop Res 124: 223-230.

14. Ghosh PK, Dayal D, Bandyopadhyay KK, Mohanty M (2006) Evaluation of straw and polythene mulch for enhancing productivity of irrigated summer groundnut. Field Crop Res 99: 76-86. 
Citation: $\quad$ Ahmadzai MA, Cai M, Meng Y, Zhou JB (2017) Effects of Water Saving Practices on Winter Wheat and Summer Maize Yields in South Loess Plateau of Northwest China. Agrotechnology 6: 157. doi:10.4172/2168-9881.1000157

Page 6 of 6

15. Zhang S, Lovdahl L, Grip H, Tong Y, Yang X, et al. (2009) Effects of mulching and catch cropping on soil temperature, soil moisture and wheat yield on the Loess Plateau of China. Soil Till Res 102: 78-86.

16. Ramalan AA, Nwokeocha CU (2000) Effects of furrow irrigation methods, mulching and soil water suction on the growth, yield and water use efficiency of tomato in the Nigerian Savanna. Agric Water Manag 45: 317-330.

17. Murungu FS, Chiduza C, Muchaonyerwa P, Mnkeni PNS (2011) Mulch effects on soil moisture and nitrogen, weed growth and irrigated maize productivity in a warm-temperate climate of South Africa. Soil Till Res 112: 58-65.

18. Tolk JA, Howell TA, Evett SR (1999) Effect of mulch, irrigation, and soil type on water use and yield of maize. Soil Till Res 50: 137-147.

19. Zhou JB, Wang CY, Zhang H, Dong F, Zheng XF, et al. (2011) Effect of water saving management practices and nitrogen fertilizer rate on crop yield and water use efficiency in a winter wheat-summer maize cropping system. Field Crop Res 122: 157-163.

20. Chen SY, Zhang XY, Pei D, Sun HY, Chen SL (2007) Effects of straw mulching on soil temperature, evaporation and yield of winter wheat: field experiments on the North China Plain. Ann Appl Biol 150: 261-268.

21. Li XY, Gong JD (2002) Effects of different ridge: furrow ratios and supplemental irrigation on crop production in ridge and furrow rainfall harvesting system with mulches. Agric Water Manag 54: 243-254.

22. Jia Y, Li FM, Wang XL, Yang SM (2006) Soil water and alfalfa yields as affected by alternating ridges and furrows in rainfall harvest in a semiarid environment. Field Crop Res 97: 167-175.

23. Wang Y, Xie Z, Malhi SS, Vera CL, Zhang Y, et al. (2009) Effects of rainfall harvesting and mulching technologies on water use efficiency and crop yield in the semi-arid Loess Plateau, China. Agric Water Manag 96: 374-382.

24. Younis A, Bhatti MZM, Riaz A, Tariq U, Arfan M, et al. (2012) Effect of different types of mulching on growth and flowering of Freesia alba cv. Aurora. Pak J Agric Sci 49: 429-433.

25. Baumhardt RL, Jones OR (2002) Residue management and paratillage effects on some soil properties and rain infiltration. Soil Tillage Res 65: 19-27.

26. Edwards L, Burney JR, Richter G, MacRae AH (2000) Evaluation of compost and straw mulching on soil-loss characteristics in erosion plots of potatoes in Prince Edward Island, Canada. Agr Ecosyst Environ 81: 217-222.

27. Huang Y, Chen L, Fu B, Huang Z, Gong J (2005) The wheat yields and water-use efficiency in the Loess Plateau: straw mulch and irrigation effects. Agric Water Manag 72: 209-222.

28. Igbadun HE, Ramalan AA, Oiganji E (2012) Effects of regulated deficit irrigation and mulch on yield, water use and crop water productivity of onion in Samaru, Nigeria. Agric Water Manag 109: 162-169.
29. Li QQ, Chen YH, Liu MY, Zhou XB, Dong BD, et al. (2007) Effect of irrigation to winter wheat on the soil moisture, evapotranspiration, and water use efficiency of summer maize in North China. T ASABE 50: 2073-2080.

30. Li R, Hou X, Jia Z, Han Q, Ren X, et al. (2013) Effects on soil temperature, moisture, and maize yield of cultivation with ridge and furrow mulching in the rainfed area of the Loess Plateau, China. Agric Water Manag 116: 101-109.

31. Yi L, Yufang S, Shenjiao Y, Shiqing L, Fang C (2011) Effect of mulch and irrigation practices on soil water, soil temperature and the grain yield of maize (Zea mays L) in Loess Plateau, China. Afr J Agric Res 6: 2175-2182.

32. Parry ML, Rosenzweig C, Iglesias A, Livermore M, Fischer G (2004) Effects of climate change on global food production under SRES emissions and socio-economic scenarios. Global Environ Change 14: 53-67.

33. Ramakrishna A, Tam HM, Wani SP, Long TD (2006) Effect of mulch on soil temperature, moisture, weed infestation and yield of groundnut in northern Vietnam. Field Crop Res 95: 115-125.

34. Rockstrom J, Lannerstad M, Falkenmark M (2007) Assessing the water challenge of a new green revolution in developing countries. Proc Natl Acad Sci 104: 6253-6260.

35. Su Z, Zhang J, Wu W, Cai D, Lv J, et al. (2007) Effects of conservation tillage practices on winter wheat water-use efficiency and crop yield on the Loess Plateau, China. Agric Water Manag 87: 307-314.

36. Sun H, Shen Y, Yu Q, Flerchinger GN, Zhang Y, et al. (2010) Effect of precipitation change on water balance and WUE of the winter wheatsummer maize rotation in the North China Plain. Agric Water Manag 97: 1139-1145.

37. Wei X, Declan C, Erda L, Yinlong X, Hui J, et al. (2009) Future cereal production in China: the interaction of climate change, water availability and socio-economic scenarios. Glob Environ Change 19: 34-44.

38. Xie ZK, Wang YJ, Li FM (2005) Effect of plastic mulching on soil water use and spring wheat yield in arid region of northwest China. Agric Water Manag 75: 71-83.

39. Qu Y, Su W, Zhang P, Li C, Gao J, et al. (2012) Effects of different water harvesting on soil water, growth and yield of the proso millet (Panicum miliaceum L.) in a semiarid region of northwest China. J Agr Sci 4: 106-113.

40. Zhou LM, Li FM, Jin SL, Song Y (2009) How two ridges and the furrow mulched with plastic film affect soil water, soil temperature and yield of maize on the semiarid Loess Plateau of China. Field Crop Res 113: 41-47. 